\title{
Do freelance independent contractors promote entrepreneurship?
}

\author{
Andrew Burke • Imran Zawwar • Stephanie Hussels
}

Accepted: 1 March 2019

(C) Springer Science+Business Media, LLC, part of Springer Nature 2019

\begin{abstract}
We investigate whether or not the level of entrepreneurial activity in an economy is determined by the availability of freelance independent contractors in the workforce. We develop hypotheses and test them through an analysis of 75 countries from 2002 to 2012 using the Global Entrepreneurship Monitor (GEM) database. We find freelance independent contractors promote entrepreneurial activity where typically a $10 \%$ rise in the freelance workforce causes about a $1 \%$ increase in entrepreneurial activity. The significance of this positive effect is robust for both necessity and opportunitydriven entrepreneurial types and across innovationdriven and efficiency-driven economies - but it is stronger in innovation-driven economies and also for necessity entrepreneurship. It implies that having a flexible workforce is a key ingredient to having an entrepreneurial economy. Furthermore, it indicates that orthodox research and public policy perspectives which overlook the importance of freelance independent contractors for entrepreneurship activity require a re-appraisal.
\end{abstract}

Keywords Freelancers $\cdot$ Contractors $\cdot$ Enabling entrepreneurship · Promoting entrepreneurship · Entrepreneurial activity

\footnotetext{
A. Burke $(\bowtie)$

Trinity Business School, Trinity College Dublin, University of Dublin, Dublin 2, Ireland

e-mail: andrew.burke@tcd.ie

I. Zawwar · S. Hussels

Cranfield School of Management, Cranfield University, Cranfield,

Bedfordshire MK43 0AL, UK
}

JEL classification $\mathrm{J} 41 \cdot \mathrm{L} 24 \cdot \mathrm{L} 26 \cdot \mathrm{M} 21 \cdot \mathrm{O} 25$

\section{Introduction}

Freelance independent contractors, also referred to as solo self-employed, have been linked as a determinant of entrepreneurial activity (Burke 2012; Audretsch et al. 2015). They are attributed the functions of both enabling entrepreneurship (Burke 2011, 2012) and also being direct providers of entrepreneurship themselves (Burke 2012; Burke and Cowling 2015). They are viewed as enablers of entrepreneurship by providing business ventures access to a flexible variable cost business model which involves lower financial requirements and risk, while simultaneously providing access to human expertise/talent beyond the confines of the employee resource base of each firm (Burke 2011, 2012). They can also be direct providers of entrepreneurship when they bring innovation to firms (Audretsch 1995; Acs and Gifford 1996). Combining the observations that freelance independent contractors are able to bring business ideas to the market by 'contracting' with many firms (Barley and Kunda 2006) and that entrepreneurs must stay committed to their business typically focusing on a single firm (Audretsch and Thurik 2004), leads to the possibility that a freelance independent contractor who provides each client firm with a unique entrepreneurial idea can repeat this activity many times with different firms and thereby drive a greater level of innovation than a business owner who has to stick with the main business 
idea/s associated with his/her own firm (Burke and Cowling 2015). While the logic supporting these arguments is plausible, so far only case study evidence exists (e.g. Burke 2011, 2012) to support the general conclusion that independent contractors promote entrepreneurship.

To the best of our knowledge, there is no statistical analysis to support the claim that the level of entrepreneurial activity in a country is dependent on the number of independent contractors active in the labour market. This shortcoming means that we are still in the dark about the key parameters linking freelancing to entrepreneurship which are of interest to research and practice. In the first instance, we do not know if case study examples (e.g. Burke 2012) showing independent contractors as enablers and/or providers of entrepreneurship are exceptions or in any way generic. Even if they prove to be or are generally accepted as being generic, we are also not aware of the extent to which freelancing promotes entrepreneurship, i.e. even if statistically significant, does the availability of independent contractors have a magnitude of impact on entrepreneurial activity that would be relevant for the attention of business practice and public policy? Furthermore, we also do not know whether any relationship between freelancing and entrepreneurship differs by type of entrepreneurship (e.g. necessity versus opportunity entrepreneurship) or by the economic context (e.g. across innovation-driven, efficiency-driven and factor-driven economies) in which the entrepreneurship is taking place.

In this paper, we address these shortcomings and use the Global Entrepreneurship Monitor (GEM) dataset across 75 countries over a 10 -year period in order to provide answers to these questions. In general, we confirm the broad argument that freelance independent contractors promote entrepreneurship but find an interesting variation in the statistical significance and power of this effect across types of entrepreneurship (opportunity and necessity) and business contexts (innovation-, efficiency- and factor-driven economies).

This article is structured as follows: in the next section of the paper, we outline the theory and hypothesis which we use to motivate and design our empirical analysis. This is followed by a section which discusses the methodology and the data. We then discuss the empirical analysis and main findings. The paper closes with an outline of the main conclusions.

\section{Theory and hypotheses}

The occupational category 'freelance independent contractors' entails the overlapping activities of running oneperson businesses with no employees, freelancers and independent contract workers (Kitching 2015; Bögenhold et al. 2014; Leighton and Brown 2013), all of which create outsourcing opportunities for firms. For the purpose of simplicity throughout the paper, we use the term independent contractors to refer to all types of activities involving solo self-employed or freelance workers. The key factors that distinguish them from employees are that they are hired for a fixed duration determined either by dates/times or by the completion of a project or defined service (DeFillipi 2001; Bakker 2010). The firm hiring independent contractors has no legal and hence financial commitment to them beyond the period or project in which they are being hired (Burke 2012, 2019). Therefore, in comparison to employees who entail a significant fixed and variable cost for firms at any point in time, independent contractors have much less and in some cases no fixed cost elements (Jahn et al. 2012). Therefore, they enable businesses to operate more extensively on a variable cost labour utilization model (Burke 2011). As a result, they require firms to have a flexible structure with less fixed and sunk costs when hiring labour in comparison to the utilization of employees who through labour law have rights that entitle them to notice period with pay, ability to claim a particular job subject to reasonable performance and redundancy payments (Liang and Goetz 2016).

Furthermore, independent contractors (particularly those who trade through their own company) are quite often paid 'a price', that is on an output basis for the successful completion of a defined piece of work rather than the more usual employee contracts where remuneration is on an input basis for labour time supplied to the firm (Guest 2004). As a result of either or both of the variable cost and output-based nature of the independent contractor's remuneration model, it follows that in comparison to employees, independent contractors enable firms to reduce the risk of hiring workers to engage in business start-ups. Therefore, they can enable entrepreneurship by both reducing capital requirements (financial constraints) and the financial risk involved (cost of finance) in new business start-up (Burke 2011). Furthermore, both lean (Ries 2011) and agile (Burke 2009) start-ups are enabled by the availability of independent contractors who can be used to outsource services, 
projects and labour expertise on a variable cost basis. In short, the availability of independent contractors reduces barriers to entry for business start-ups and reduces the scale disadvantage that new relatively smaller firms have in comparison to large incumbents (Burke 2012).

Independent contractors enable firms to hire a greater diversity of workers because hiring on a per project or limited time period basis allows a firm to hire a greater number of workers for short periods than would be the case when using the same budget to hire employees continuously over the same period (Atkinson 1984). Furthermore, as long as the firm wants greater diversity in specialized skilled labour or experience, then labour costs using independent contractors are likely to be lower as they avoid the costs of idle downtime that results when specialized workers are not needed for specific periods on a project (Burke 2011). The net result of these effects is that they enable new start-ups to be able to have the capacity to deliver projects using a great variety of contract workers that enables them to compete against much larger organizations who achieve similar diversity at much greater costs using a mainly employee workforce (Burke 2012). Using freelance independent contractors has also enabled larger firms to adopt project-based organisation forms in order to become more agile and innovate; so sustaining them in dynamic entrepreneurial business environments (Burke 2019).

So in sum, the availability of independent contractors might enable new business start-up activity (both opportunity and necessity) by lowering financial constraints, cost and risk as well as also enhancing the capability of these firms to deliver beyond the limitations of their internal employee base. Since independent contractors are providers of entrepreneurship to firms by being sources of entrepreneurial ideas and innovation for firms (Burke and Cowling 2015), this strengthens their role in facilitating opportunity-driven entrepreneurial activity in the economy. Combined, they provide a major resource base upon which new business start-up activity is enabled and can thrive. Similarly, as necessity entrepreneurs are less agile than opportunity entrepreneurs (Block et al. 2015), the presence of independent contractors is expected to positively impact the levels of new necessity-driven entrepreneurial activity too. This generates our first three hypotheses.

Hypothesis 1: A larger pool of independent contractors in the workforce causes greater levels of new entrepreneurial activity
Hypothesis 2: A larger pool of independent contractors in the workforce causes greater levels of new opportunity-driven entrepreneurial activity Hypothesis 3: A larger pool of independent contractors in the workforce causes greater levels of new necessity-driven entrepreneurial activity

The main difference between opportunity- and necessity-driven entrepreneurship is that the former is often viewed as typically having higher business potential (Reynolds et al. 2002) and requires greater financial and human capital requirements (Evans and Jovanovic 1989). If this is true then since the use of independent contractors by firms has the potential to reduce their financial and human capital constraints, it follows that one might expect the magnitude of any positive impact of independent contractors on new entrepreneurial activity to be stronger for opportunity- rather than necessitydriven entrepreneurship as stated in hypothesis 4 .

Hypothesis 4: A larger pool of independent contractors in the workforce will have a stronger impact in promoting new opportunity-driven than necessity-driven entrepreneurial activity

The U-shaped relationship between entrepreneurial activity and economic development has been well documented (Wennekers et al., 2005, 2010; Acs et al. 1994). In terms of economic development, innovationdriven economies are seen as the most developed, followed by efficiency-driven and then factor-driven economies (Porter et al. 2002). The workforces of both innovation-driven and factor-driven economies will have a greater inclination towards entrepreneurial activity than the workforces in efficiency-driven economies (Acs et al. 2008). This is driven by factors that promote entrepreneurship being typically more prevalent in innovation-driven economices. These include more developed entrepreneurial ecosystems to support new entrepreneurs, a greater supply of entrepreneurial finance, greater person wealth and hence an ability to selffinance start-ups, earlier access to new technologies, greater proportion of industries with lower barriers to entry and minimum efficient scale, and more affluent and adventurous consumers who provide new opportunities for entrepreneurs in these economies before others (Bhide 2008). So, for any given percentage increase in freelancing in the workforce, one might expect it to unleash a greater percentage increase in total 
entrepreneurial activity (TEA) in innovation-driven economies than in efficiency-driven economies where these factors are less prevalent. As a result, one ought to expect the availability of independent contractors to have the lowest impact in efficiency-driven economies compared to all other types of economy. In the next section of the paper, we will explain that data restrictions prevent us from doing statistically meaningful comparative analysis with factor-driven economies and so the following hypotheses only relate to comparisons between innovation- and efficiency-driven economies. So our arguments lead to the following hypothesis:

Hypothesis 5: The impact of independent contractors promoting entrepreneurial activity will be stronger for innovation-driven economies compared to efficiency-driven economies

The types of entrepreneurship will vary in innovationdriven economies with a greater prevalence of opportunity-driven entrepreneurs as compared to necessity-driven entrepreneurs (Bhide 2008; Acs et al. 2008). Therefore, independent contractors can be expected to have a greater impact in promoting opportunitydriven entrepreneurial activity in innovation-driven economies. This leads to our last hypothesis:

Hypothesis 6: Within innovation-driven economies, the benefits from independent contractors will have a greater impact in promoting opportunitydriven rather than necessity-driven entrepreneurial activity

We now move our attention to the testing of these hypotheses.

\section{Data and methodology}

\subsection{Data and variables explained}

We make use of the GEM dataset comprising 75 countries from 2002 to 2012 to study the impact of independent contractors on entrepreneurial activity. Although the total number of countries represented in GEM during this period is greater, some countries got dropped from the analysis due to insufficient data (see Table 5 in the Appendix for the list of countries included in our dataset). Our preference for GEM over other available datasets is driven because of its unique focus on individual entrepreneurs and their characteristic features (Reynolds et al. 1999), which allows us to purge the data and to individually recognize independent contractors among the respondents. In addition to the data from GEM, we use a variety of other databases to select our control variables including Penn World Table (PWT) 8.1, World Development Indicators, World Economic Outlook and Transparency International.

We use the index of Total early-stage Entrepreneurial Activity (TEA) as a metric to measure our dependent variable, i.e. early-stage entrepreneurial activity in the country. In the literature, several proxies for measuring entrepreneurship are adopted including VAT registration, self-employed ratio and business registration data (Acs et al. 2012; Burke and Hussels 2013). Our choice of TEA is based on the fact that it is the single most comprehensive measure which accounts for both the rate of nascent entrepreneurial activity and the percentage of new businesses less than 42 months of age. Secondly, there is no other database that provides data for this wide variety of countries and over such an extended period of time allowing the countries to be classified according to their stages of development. Finally, with TEA being a weighted score taking into consideration the age and gender of the individuals in respective countries and also allowing longitudinal data across all countries in the dataset being harmonized using a common variable coding scheme, TEA provides the most suitable measure. TEA is derived from the GEM Adult Population Survey aggregated at the Global National Level and it is based on strict sample requirements including a minimum of 2000 survey respondents per country (Reynolds et al. 2002).

To measure the percentage of independent contractors within each economy, we make use of the Individual Level GEM Adult Population Survey to generate a new index measuring independent contractors. The protocol that we follow is to segregate the independent contractors in the GEM dataset involving three distinct steps. In the first step, we filter the respondents on the basis of their age, selecting only those between 18 and 64 years, because it is at this age individuals are qualified as being active in the labour force. In the second step, we filter the dataset based on the number of people currently working for the business (excluding the owners) and only select those businesses with no current employees. In the third step, we further refine this dataset and select only those businesses with a single owner and manager. The three- 
step process provides us a unique sample of independent contractors operating in the economy. However, in order to ensure that this does not overlap with the observations in TEA, we further refine this by selecting only the established independent contractors, i.e. those older than 42 months and filtering out newborn business independent contractors who are less than 42 months old and part of TEA. From a theoretical point of view, we only consider established independent contractors because they are more established and hence provide realistic sub-contracting or outsourcing opportunities for the new ventures. Put differently, using more proven established independent contractors reduces noise from the data by limiting volatility from disproportionately high levels of business deaths among early-stage independent contractors. Thus, our proxy for independent contractors is the percentage of 18-64 population who are solo ownermanagers of a business with no other person working for them and the business they own is older than 42 months. Further, in order to normalize the data on TEA and independent contractors, we use the log transformation of their respective ratios. An advantage of this is that estimated coefficients can be interpreted directly as elasticities (see Table 7 in the Appendix for the descriptive statistics on independent contractors and TEA).

In addition to the percentage of independent contractors in the economy, there are numerous other factors and variables, both economic and non-economic, which determine the rate of entrepreneurial activity in a country (Wennekers et al. 2010). There is an extensive literature on such variables and their influence on entrepreneurship (Wennekers et al. 2005; Verheul et al. 2002). On the basis of this extant literature, we select a number of independent variables as our controls to test our hypotheses. In this regard, an important manifestation of entrepreneurial growth is the increase in income per capita (Wong et al. 2005), but earlier as we have focused on the use of population active in the labour force for measuring TEA and independent contractors (i.e. percentage of 18-64 population), we choose income per worker $^{1}$ as our choice for an independent control variable.

With unemployment having an impact on the state of entrepreneurship (Storey 1991; Armington and Acs 2002; Fritsch and Mueller 2007; Fritsch and Falck 2007), we use it as a control by measuring the share of

\footnotetext{
${ }^{1}$ The measure of GDP used in our analysis is in PPP at constant prices of 2011 in USD, having data in PPP ensures comparison across the countries while holding it constant at 2011 prices ensures comparability across time (see Feenstra et al. (2015)).
}

the labour force that is without work, but available for and seeking employment. Human capital is another determinant of entrepreneurial success, interest in it has remained longstanding by entrepreneurial researchers and it has taken a surge in the last two decades (Marvel et al. 2016; Unger et al. 2011), as more data has become available especially on entrepreneurial activity. This paper utilizes the measure of human capital derived from PWT 8.1 which is constructed using average years of schooling interpolated from Barro and Lee (2013) and country-specific estimates for returns to primary, secondary and tertiary education (Psacharopoulos and Patrinos 2004). Population growth is also considered as an important factor in determining economic growth (Barro 1998), and by consequence, this may impact entrepreneurial activity in a country. Following the traditional growth models in economics, we adopt technology-augmented population growth, and it is measured as $n_{i, t}+(g+d)$ where $n_{i, t}$ is the natural yearly rate of growth of population, while $g$ is labouraugmented technological progress and $d$ is the rate of depreciation of physical capital. $^{2}$

A country may have a positive economic outlook but if it has higher levels of corruption, this may inflict a blow to its economic growth and by consequence to the entrepreneurial activity (Karmann et al. 2016; Anokhin and Schulze 2009). We therefore add the level of corruption as measured by the corruption perception index as a control variable. Reynolds et al. (2002) argue that among factors that contribute to higher levels of entrepreneurial activity, entrepreneurial attitudes and aspirations are of vital importance. To cater for this, we use perceived capability and market growth potential from GEM as additional controls. For more details on the definitions of variables and their respective sources, see Table 6 in the Appendix.

\subsection{Method of analysis}

We carry out a series of nine regressions to test our hypothesized relationships between TEA and the independent contractors in an economy. First, we estimate the entire global sample with 75 countries and then divide the countries in our dataset according to Porter's stages of economic development (Porter et al. 2002). Secondly, we segregate the dependent variable TEA into opportunity TEA and necessity TEA as per the GEM

\footnotetext{
$\overline{{ }^{2} \text { We choose } 0.05}$ as the value for $(g+d)$ (see Caselli et al. 1996; Islam 1995 and Mankiw et al. 1992).
} 
classifications. Once we tabulate these into a matrix framework, it provides us with twelve different interactions based on which we conduct our regressions and test our hypotheses (see Table 4).

To test our hypotheses, we use FGLS estimations to deal with the problem of heteroscedasticity caused by the number of countries in the dataset and generate asymptotically efficient estimations. With the Breusch-Pagan test confirming heteroscedastic errors and the Wooldridge test for autocorrelation confirming no first-order autocorrelation in the sample, FGLS estimation is adopted as it provides asymptotically efficient estimations and is, therefore, our preferred choice (Wooldridge 2002).

\section{Empirical analysis}

\subsection{Aggregate world sample}

Table 1 presents the test statistics of the empirical results using TEA in the economy as a whole. The positive and statistically significant coefficients of the independent contractors irrespective of the type of entrepreneurship suggest that it tends to be positively related to entrepreneurial activity. This confirms that independent contractors have an enabling positive effect on all types of entrepreneurship (both opportunity and necessity) and therefore we accept our hypotheses 1,2 and 3. Although the data shows an enabling effect of independent contractors on all types of entrepreneurship, hypothesis 4 is rejected as results reveal that independent contractors have a stronger impact on promoting necessity-driven entrepreneurial activity. Our results on unemployment are in line with the arguments put forward by ForemanPeck (1985) who suggests there will be a higher proportion of less able entrepreneurs among those who are pushed (necessity) into business start-up than those who were pulled (opportunity) into it. The comparison of the coefficient of unemployment in Table 1 justifies this argument. These results are also in line with the 'push' and 'pull' effect models (Thurik et al. 2008), as an increase in unemployment increases necessity entrepreneurial activity, while it reduces the rate of opportunity-based entrepreneurship (although not significantly).

Similarly, an increase in the income potential, i.e. GDP per worker, negatively affects entrepreneurial activity as people get more attracted to seeking job opportunities in the market as opposed to pursuing entrepreneurship. However, this impact is stronger on necessity entrepreneurial activity as compared to opportunitybased entrepreneurs, because as the economy thrives, the necessity 'push' diminishes. In the same context, an increase in human capital improves the job prospects for highly educated workers and interestingly its drain on opportunity entrepreneurial activity is greater than necessity-driven entrepreneurship. Technologyaugmented population growth has the maximum impact (in terms of regression) in improving entrepreneurial activity and it is significantly strong in promoting opportunity-driven entrepreneurship but insignificant for necessity entrepreneurship.

Interestingly the results in Table 1 suggest that an increase in corruption perception index (i.e. reduction in corruption) has a negative impact on necessity entrepreneurship; in other words, an increase in corruption promotes necessity entrepreneurship. This implies that as informal economic practices dominate the economic system, acts like bribery may allow the entrepreneurs to avoid bureaucratic delays and translate them into significant gains (Leff 1964). However, such gains do not materialize for opportunity entrepreneurship probably because corruption damages innovative practices, distorts resource allocation and promotes inequality which tends to be unfavourable for economic growth and development (Gould and Amaro-Reyes 1983; Murphy et al. 1993; Mauro 1995). Finally, an increase in perceived capability and market growth potential translates into a positive impact on entrepreneurial activity.

\subsection{Innovation-driven versus efficiency-driven countries}

Tables 2 and 3 show that an increase in independent contractors in the workforce in innovation-driven economies has a greater impact on entrepreneurial activity as compared with efficiency-driven economies. This supports our hypothesis 5 and provides support for the middle and the last part of the U-shaped relationship between entrepreneurial activity and economic development. Unfortunately, we are unable to continue the comparative analysis for factor-driven economies due to an insufficient number of observations for this type of economy and so cannot comment on the first (downward sloping) part of the U-shaped relationship between entrepreneurial activity and economic development.

Tables 2 and 3 indicate that an increase in human capital in these countries reduces entrepreneurial activity. The negative effect for human capital in these economies 
Table 1 Aggregate world sample

\begin{tabular}{|c|c|c|c|}
\hline \multirow[t]{2}{*}{ Whole world } & \multicolumn{3}{|l|}{ FGLS } \\
\hline & $\operatorname{Ln}(\mathrm{TEA})$ & Ln(opportunity TEA) & Ln(necessity TEA) \\
\hline Ln independent contractors & $0.0798 * * *(7.89)$ & $0.0932 * * *(8.72)$ & $0.1395 * * *(9.05)$ \\
\hline Ln GDP per worker (i.e. income) & $-0.1371 * * *(-7.75)$ & $-0.0682 * * *(-3.62)$ & $-0.2888^{* * *}(-8.44)$ \\
\hline Ln unemployment & $0.0379 *(1.76)$ & $-0.0331(-1.29)$ & $0.3277 * * *(7.38)$ \\
\hline Ln human capital & $-0.4154 * * *(-4.77)$ & $-0.4638 * * *(-4.78)$ & $-0.3697 * *(-2.47)$ \\
\hline Tech-augmented population growth & $8.6853 * * *(6.51)$ & $10.1651 * * *(6.72)$ & $1.0129(0.49)$ \\
\hline CPI & $-0.0163^{* * *}(-2.61)$ & $0.0067(1.03)$ & $-0.1392 * * *(-11.46)$ \\
\hline Perceived capability & $0.0037 * * *(4.84)$ & $0.0051 * * *(5.81)$ & $0.0000(0.03)$ \\
\hline Ln market growth potential & $0.3473 * * *(20.71)$ & $0.3366 * * *(17.61)$ & $0.4013 * * *(15.28)$ \\
\hline Wald & 4613.94 & 2456.64 & 3106.29 \\
\hline$p$ value & 0.00 & 0.00 & 0.00 \\
\hline Number of groups & 74 & 74 & 74 \\
\hline Number of observations & 386 & 386 & 386 \\
\hline
\end{tabular}

$*, * *$ and $* * *$ determine the level of significance at $10 \%, 5 \%$ and $1 \%$ respectively. Bracket (.) provides $t$ statistics for the respective coefficients. Estimates for year dummies are not presented but can be provided upon request. All calculations are conducted by STATA 12.0

probably means there are many good wage jobs available for highly educated workers, i.e. in such economies, wage employment is more attractive than entrepreneurship (see Lucas 1978; Kher et al. 2012). On the contrary, an increase in unemployment has a negative effect on entrepreneurial activity in innovation-driven countries, consistent with the prosperity-pull effect (Thurik et al. 2008), except for necessity entrepreneurial activity as seen in Table 2 . Table 2 also shows that an increase in independent contractors in innovation-driven countries has a greater impact on necessity TEA as compared to opportunity TEA. This means we cannot accept our 6th hypothesis.

Table 4 presents the summary results, linking them with the hypotheses and showing the positive and statistically significant coefficients of the independent contractors irrespective of the type of entrepreneurship and the level of

Table 2 Innovation-driven countries

\begin{tabular}{llll}
\hline Innovation-driven countries & FGLS & & \\
\cline { 2 - 4 } & Ln(TEA) & Ln(opportunity TEA) & Ln(necessity TEA) \\
\hline Ln independent contractors & $0.1128^{* * *(5.38)}$ & $0.1191 * * *(5.04)$ & $0.1987 * * *(3.78)$ \\
Ln GDP per worker (i.e. income) & $-0.2858^{* * *}(-5.16)$ & $-0.2161 * * *(-3.71)$ & $-0.1718(-1.32)$ \\
Ln unemployment & $-0.0880^{* *}(-2.09)$ & $-0.1312^{* * *(-2.75)}$ & $0.0740(0.94)$ \\
Ln human capital & $-0.2152(-1.30)$ & $-0.3834 * *(-2.07)$ & $0.0739(0.21)$ \\
Tech-augmented population growth & $14.4149^{* * *}(7.11)$ & $16.7293 * * *(7.42)$ & $13.0947 * * *(3.05)$ \\
CPI & $-0.1626(-1.24)$ & $-0.0014(-0.10)$ & $-0.1579 * * *(-5.83)$ \\
Perceived capability & $0.0025^{* *}(2.05)$ & $0.0040^{* * *}(3.07)$ & $-0.0008(-0.34)$ \\
Ln market growth potential & $0.3164 * * *(12.48)$ & $0.2834 * * *(10.41)$ & $0.3143 * * *(6.30)$ \\
Wald & 596.97 & 555.48 & 235.70 \\
$p$ value & 0.00 & 0.00 & 0.00 \\
Number of groups & 27 & 27 & 27 \\
Number of observations & 194 & 194 & 194 \\
\hline
\end{tabular}

$*, * *$ and $* * *$ determine the level of significance at $10 \%, 5 \%$ and $1 \%$ respectively. Bracket (.) provides $t$ statistics for the respective coefficients. Estimates for year dummies are not presented but can be provided upon request. All calculations are conducted by STATA 12.0 
Table 3 Efficiency-driven countries

\begin{tabular}{llll}
\hline Efficiency-driven countries & FGLS & & \\
\cline { 2 - 4 } & Ln(TEA) & Ln(opportunity TEA) & Ln(necessity TEA) \\
\hline Ln independent contractors & $0.0855^{* * *(6.15)}$ & $0.0875^{* * *}(5.87)$ & $0.1633^{* * *}(6.80)$ \\
Ln GDP per worker (i.e. income) & $-0.0630^{* *}(-2.30)$ & $0.0037(0.13)$ & $-0.1296^{* * *}(-3.09)$ \\
Ln unemployment & $0.1091^{* * *(3.58)}$ & $0.0029(0.11)$ & $0.4267 * * *(7.61)$ \\
Ln human capital & $-0.7125^{* * *(-4.84)}$ & $-0.7356^{* * *(-4.93)}$ & $-0.9633 * * *(-4.83)$ \\
Tech-augmented population growth & $-0.8951(-0.44)$ & $1.9179(0.86)$ & $-0.1979(-0.06)$ \\
CPI & $-0.0043(-0.28)$ & $0.0369 * *(2.14)$ & $-0.0822 * * *(-3.71)$ \\
Perceived capability & $0.0033^{* * *(2.81)}$ & $0.0057 * * *(4.59)$ & $-0.0000(-0.02)$ \\
Ln market growth potential & $0.3902^{* * *(15.66)}$ & $0.3911 * * *(14.70)$ & $0.3729 * * *(8.94)$ \\
Wald & 1286.96 & 1637.94 & 629.62 \\
$p$ value & 0.00 & 0.00 & 0.00 \\
Number of groups & 34 & 34 & 34 \\
Number of observations & 163 & 163 & 163
\end{tabular}

$* * *$ and $* * *$ determine the level of significance at $10 \%, 5 \%$ and $1 \%$ respectively. Bracket (.) provides $t$ statistics for the respective coefficients. Estimates for year dummies are not presented but can be provided upon request. All calculations are conducted by STATA 12.0

economic development. Figure $1 \mathrm{a}-\mathrm{c}$ in the Appendix presents the graphical relationship between total entrepreneurial activity and independent contractors in all of the three economic conditions plus the world as an aggregate.

\section{Conclusions and implications}

In this paper, we research the impact of independent contractors on entrepreneurial activity across 75 countries over the period of 2002 to 2012 . We find that entrepreneurship levels are dependent on the availability of independent contractors in the workforce. In general, a $10 \%$ increase in independent contractors causes around a $1 \%$ increase in entrepreneurial activity.

Our paper makes three main contributions. First, it challenges the current entrepreneurship research that tends to view independent contractors mainly as the low performance end of entrepreneurship, i.e. ventures that do not hire any employees with marginal economic impact. Our quantitative analysis hence supports a growing theoretical but predominately qualitative research trajectory that indicates that independent contractors enable entrepreneurship. It supports the conclusion

Table 4 Summary matrix

\begin{tabular}{|c|c|c|c|c|}
\hline Freelance workers (FW) & \multicolumn{2}{|c|}{$\operatorname{Ln}(\mathrm{TEA})$} & Ln(opportunity TEA) & Ln(necessity TEA) \\
\hline \multirow[t]{3}{*}{ All the countries in the sample } & \multicolumn{2}{|c|}{$0.0798 * * *$} & $0.0932 * * *$ & $0.1395 * * *$ \\
\hline & \multirow{2}{*}{\multicolumn{2}{|c|}{$\mathrm{H}_{1}$}} & $\mathrm{H}_{2}$ & $\mathrm{H}_{3}$ \\
\hline & & & $\mathrm{H}_{4}$ & \\
\hline \multirow[t]{2}{*}{ Innovation-driven countries } & \multirow[t]{2}{*}{$\mathrm{H}_{5}$} & \multirow[t]{2}{*}{$0.1128 * * *$} & $0.1191 * * *$ & $0.1987 * * *$ \\
\hline & & & $\mathrm{H}_{6}$ & \\
\hline Efficiency-driven countries & & $0.0855 * * *$ & $0.0875 * * *$ & $0.1633 * * *$ \\
\hline
\end{tabular}

Note: This table serves the purpose of linking the results with the hypothesis in order to provide an overview of the context that is being argued in this paper. For example, $\mathrm{H}_{1}, \mathrm{H}_{2}$ and $\mathrm{H}_{3}$ test the impact of independent contractors for different measures of entrepreneurship in the overall sample. Similarly, $\mathrm{H}_{4}$ and $\mathrm{H}_{6}$ compare the impact of independent contractors on opportunity and necessity TEA in different business contexts. While $\mathrm{H}_{5}$ compares the impact of having independent contractors in the workforce under different business contexts. The two hypotheses, $\mathrm{H}_{4}$ and $\mathrm{H}_{6}$, were rejected while all others were accepted

*** Determines the level of significance at $1 \%$ 
that entrepreneurs need access to independent contractors to enable business start-up. Put simply, more independent contractors enhance total entrepreneurial activity.

Second, we find a positive relationship between independent contractors and entrepreneurial activity which holds for both opportunity-driven and necessity-push entrepreneurial activity implying that independent contractors promote entrepreneurial activity irrespective of the type of entrepreneurship. Moreover, testing for the impact of the economic context, we find that these results hold for both innovation-driven and efficiency-driven economies but importantly are stronger for innovationdriven economies. The positive impact of the availability of independent contractors hence holds for various types of entrepreneurship and for economies regardless of the stage of their economic development. In addition, we find that the availability of independent contractors in the workforce has a stronger impact on necessity-driven entrepreneurship irrespective of the economic context. Put differently, the availability of independent contractors helps promote the most disadvantaged type of entrepreneurship most likely by reducing some of the usual constraints associated with necessity entrepreneurship associated with financial and human capital constraints. More generally, an increase in independent contractors produces a positive impact as the findings appear to indicate that independent contractors have an enabling effect for every kind of entrepreneurship under all economic conditions. Unfortunately, we could not test the factor-driven economies due to the limited availability of data for these countries.

Third, with current public policies mainly focusing on promoting ventures with the potential for growth and the ambition to hire more employees, our findings suggest that enterprise policy may be overly discriminating against or ignoring independent contractors or businesses without ambitions to hire employees. Our research shows that the economic impact of independent contractors extends beyond their own performance and impacts on the level of entrepreneurship more generally. From a pure research perspective, the results unearth a new dimension to the entrepreneurial ecosystem where having an active freelance workforce helps underpin and spawn a more active entrepreneurial community. This also implies new areas for exploration in fields of research on regional clusters, endogenous economic growth and the impact of context (particularly labour market) on entrepreneurial activity.

\section{Appendix}

(a) Aggregate world sample

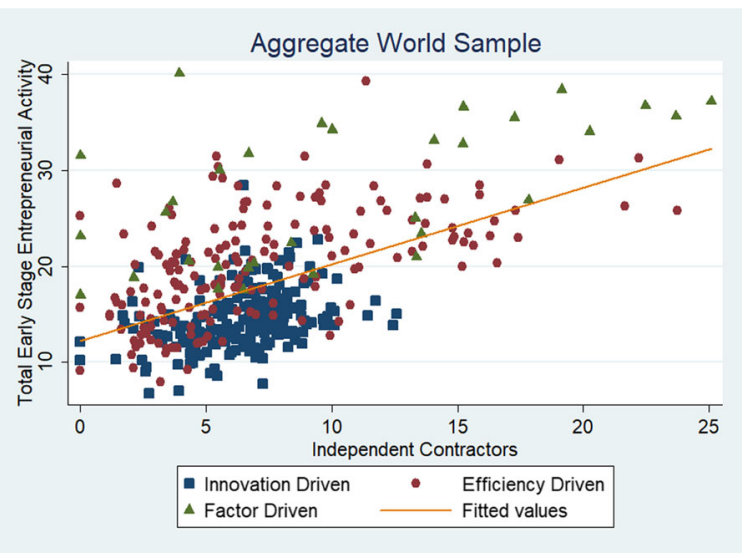

(b) Innovation driven countries.

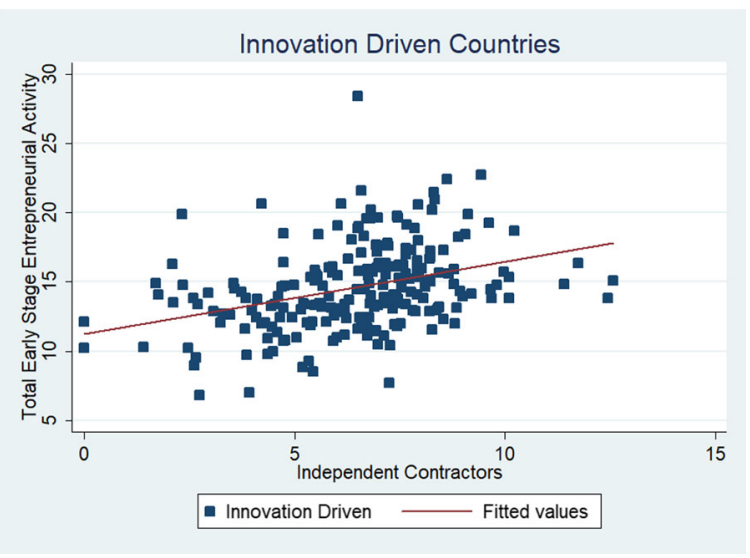

(c) Efficiency driven countries

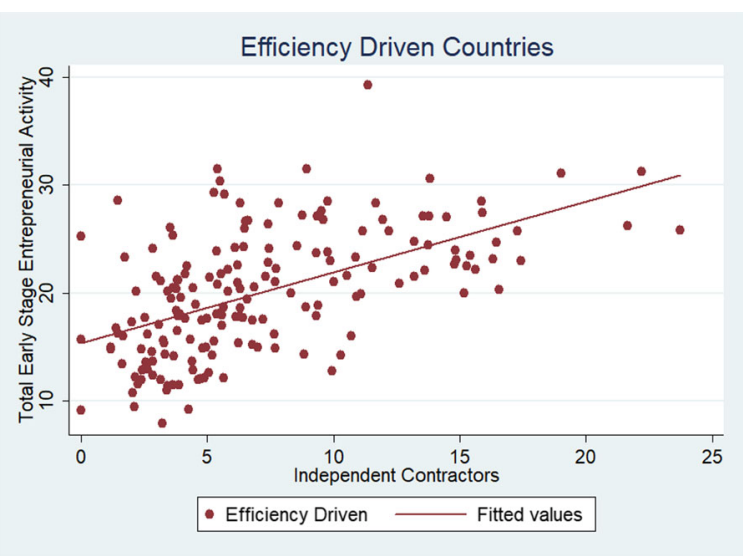

Fig. 1 Correlation between TEA and independent contractors. a Aggregate world sample. b Innovation-driven countries. c Efficiency-driven countries 


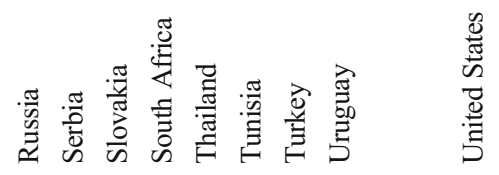

हूँ

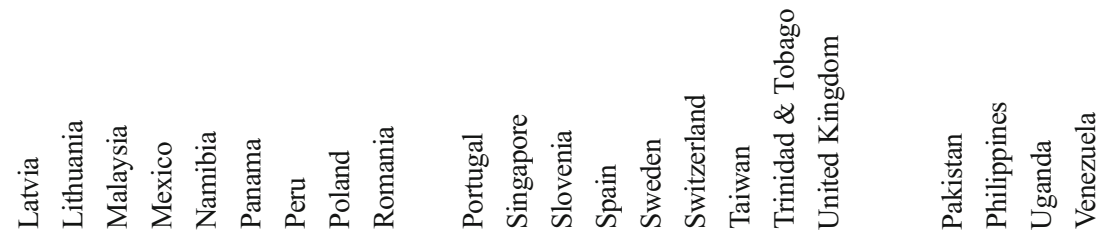

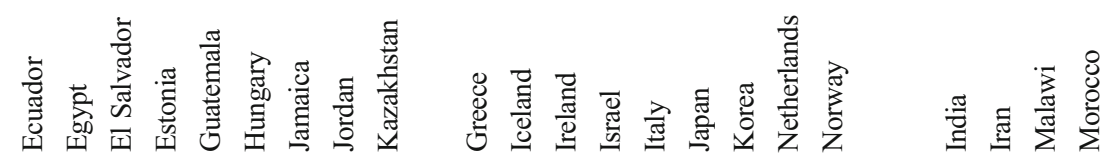


Table 6 Summary description of variables and data sources

\begin{tabular}{|c|c|c|}
\hline Variable & Definition & Sources \\
\hline $\begin{array}{l}\text { Ln Total Entrepreneurial } \\
\text { Activity (TEA) }\end{array}$ & $\begin{array}{l}\text { Natural log of the percentage of the } 18-64 \text { population who } \\
\text { are either a nascent entrepreneur or owner-manager of a } \\
\text { new business (less than } 42 \text { months old) }\end{array}$ & Global Entrepreneurship Monitor (GEM) \\
\hline $\begin{array}{l}\text { Ln independent } \\
\text { contractors }\end{array}$ & $\begin{array}{l}\text { Natural log of the percentage of } 18-64 \text { population who are } \\
\text { solo owner-manager of a business with no other person } \\
\text { working for them and the business they own is older than } \\
42 \text { months }\end{array}$ & $\begin{array}{l}\text { Own calculation using Global Entrepreneurship } \\
\text { Monitor (GEM) }\end{array}$ \\
\hline Ln necessity TEA & $\begin{array}{l}\text { Natural log of the percentage of } 18-64 \text { population who are } \\
\text { involved in entrepreneurship because they had no better } \\
\text { choice for work }\end{array}$ & Global Entrepreneurship Monitor (GEM) \\
\hline Ln opportunity TEA & $\begin{array}{l}\text { Natural log of the percentage of } 18-64 \text { population who } \\
\text { claim to be driven by opportunity as opposed to finding } \\
\text { no other option for work }\end{array}$ & Global Entrepreneurship Monitor (GEM) \\
\hline Perceived capability & $\begin{array}{l}\text { Percentage of 18-64 population who believe they have the } \\
\text { required skills and knowledge to start a business }\end{array}$ & Global Entrepreneurship Monitor (GEM) \\
\hline $\begin{array}{l}\text { Technology-augmented } \\
\text { population growth }\end{array}$ & $\begin{array}{l}\text { Yearly rate of total population growth }+0.05 \text { to account for } \\
\qquad(g+d)\end{array}$ & The data on population is from WDI \\
\hline $\begin{array}{l}\text { Ln human capital } \\
\text { per worker }\end{array}$ & $\begin{array}{l}\text { Natural log of the index of human capital based on years of } \\
\text { schooling and returns to education }\end{array}$ & Penn World Tables (PWT) 8.1 \\
\hline Ln GDP per worker & $\begin{array}{l}\text { Natural log of the GDP per worker of the incumbent } \\
\text { country. The measure of GDP is in Purchasing Power } \\
\text { Parity (PPP) constant 2011, US\$ }\end{array}$ & $\begin{array}{l}\text { GDP per worker of the incumbent country. The } \\
\text { measure of GDP is in Purchasing Power Parity } \\
\text { (PPP) constant 2011, US\$ }\end{array}$ \\
\hline Ln unemployment & $\begin{array}{l}\text { Natural log of unemployment refers to the share of the } \\
\text { labour force that is without work but available for and } \\
\text { seeking employment. }\end{array}$ & $\begin{array}{l}\text { World Development Indicators (WDI) ILO } \\
\text { estimates }\end{array}$ \\
\hline $\begin{array}{l}\text { Ln market growth } \\
\text { potential }\end{array}$ & $\begin{array}{l}\text { Natural log of the percentage of } 18-64 \text { population who } \\
\text { expect market to have significant expansion potential on } \\
\text { a four-point scale }[1-4 ; 4 \text { highest] }\end{array}$ & Global Entrepreneurship Monitor (GEM) \\
\hline CPI & $\begin{array}{l}\text { Corruption perception index on a scale of } 1-10 \text { with } 1 \\
\text { being most corrupt and } 10 \text { being least corrupt }\end{array}$ & Transparency International \\
\hline Year dummies & Dummy variable for the years from 2002 to 2012 & Own calculations \\
\hline
\end{tabular}

Table 7 Descriptive statistics of independent contractors and TEA

\begin{tabular}{|c|c|c|c|c|c|c|}
\hline \multirow[t]{2}{*}{ Stages of economic development } & \multicolumn{3}{|c|}{ Independent contractors } & \multicolumn{3}{|c|}{ Total entrepreneurial activity (TEA) } \\
\hline & No. of observations & Mean & Std. Dev. & No. of observations & Mean & Std. Dev. \\
\hline Whole world & 428 & 1.95 & 2.48 & 460 & 10.07 & 7.06 \\
\hline Innovation driven & 222 & 1.38 & 0.81 & 235 & 6.53 & 2.82 \\
\hline Efficiency driven & 174 & 2.18 & 2.81 & 192 & 12.34 & 6.75 \\
\hline Factor driven & 32 & 4.56 & 5.10 & 33 & 22.12 & 10.61 \\
\hline
\end{tabular}




\section{References}

Acs, Z. J., \& Gifford, S. (1996). Innovation of entrepreneurial firms. Small Business Economics, 8(3), 203-218.

Acs, Z. J., Audretsch, D. B., \& Evans, D. S. (1994). Why does the self-employment rate vary across countries and over time. London: CEPR.

Acs, Z. J., Desai, S., \& Hessels, J. (2008). Entrepreneurship, economic development and institutions. Small Business Economics, 31(3), 219-234.

Acs, Z. J., Audretsch, D. B., Braunerhjelm, P., \& Carlsson, B. (2012). Growth and entrepreneurship. Small Business Economics, 39(2), 289-300.

Anokhin, S., \& Schulze, W. S. (2009). Entrepreneurship, innovation, and corruption. Journal of Business Venturing, 24(5), 465-476.

Armington, C., \& Acs, Z. J. (2002). The determinants of regional variation in new firm formation. Regional Studies, 36(1), 3347.

Atkinson, J. (1984). Manpower strategies for flexible organizations. Personnel Management, 16, 28-31.

Audretsch, D. B. (1995). Innovation and industry evolution. Cambridge: The MIT Press.

Audretsch, D., \& Thurik, R. (2004). A model of the entrepreneurial economy. International Journal of Entrepreneurship Education, 2, 143-166.

Audretsch, D. B., Kuratko, D. F., \& Link, A. N. (2015). Making sense of the elusive paradigm of entrepreneurship. Small Business Economics, 45(4), 703-712.

Bakker, R. M. (2010). Taking stock of temporary organizational forms: a systematic review and research agenda. International Journal of Management Reviews, 12(4), 466486.

Barley, S. R., \& Kunda, G. (2006). Contracting: a new form of professional practice. Academy of Management Perspectives, 20(1), 45-66.

Barro, R. J. (1998). Determinants of economic growth: a cross country empirical study. Cambridge: MIT Press.

Barro, R. J., \& Lee, J. W. (2013). A new data set of educational attainment in the world, 1950-2010. Journal of Development Economics, 104, 184-198. Available at: https://doi. org/10.1016/j.jdeveco.2012.10.001.

Bhide, A. (2008). The venturesome economy: how innovation sustains prosperity in a more connected world. Princeton and Oxford: Princeton University Press.

Block, J. H., Kohn, K., Miller, D., \& Ullrich, K. (2015). Necessity entrepreneurship and competitive strategy. Small Business Economics, 44(1), 37-54.

Bögenhold, D., Heinonen, J., \& Akola, E. (2014). Entrepreneurship and independent professionals: social and economic logics. International Advances in Economic Research, 20(3), 295-310.

Burke, A. (2009). Strategies for entrepreneurial success. Journal of Strategic Management Education, 5(1), 33-44.

Burke, A. (2011). The entrepreneurship enabling role of freelancers: theory with evidence from the construction industry. International Review of Entrepreneurship, 9(3), 131-158.

Burke, A. (2012). The role of freelancers in the 21st century British economy. London: PCG.
Burke, A. E. (2019). The freelance project and gig economies of the $21 \mathrm{st}$ century. London: PCG. http://crse.co. uk/sites/default/files/The $\% 20$ Freelance $\% 20$ Project $\% 20$ and $\% 20$ Gig $\% 20$ Economies $\% 20$ of $\% 20$ the $\% 2021$ st $\% 20$ Century.pdf.

Burke, A., \& Cowling, M. (2015). The use and value of freelancers: the perspective of managers. In A. Burke (Ed.), The handbook of research on freelancing and self-employment (pp. 1-14). Senate Hall: Dublin.

Burke, A. \& Hussels, S., 2013. How competition strengthens startups. Harvard Business Review, 91(3).

Caselli, F., Esquivel, G., \& Lefort, F. (1996). Reopening the convergence debate: a new look at cross-country growth empirics. Journal of Economic Growth, 1(3), 363-389.

DeFillipi, R. J. (2001). Introduction: project-based learning, reflective practices and learning outcomes. Management Learning, 32, 5-10.

Evans, D. S., \& Jovanovic, B. (1989). An estimated model of entrepreneurial choice under liquidity constraints. Journal of Political Economy, 97(4), 519-535.

Feenstra, R. C., Inklaar, R., \& Timmer, M. P. (2015). The next generation of the Penn World Table. American Economic Review, 105(10), 3150-3182.

Foreman-Peck, J. (1985). Seedcorn or chaff? New firm formation and the performance of the interwar economy. Economic History Review, 38(3), 402-422.

Fritsch, M., \& Falck, O. (2007). New business formation by industry over space and time: a multidimensional analysis. Regional Studies, 41(2), 157-172.

Fritsch, M., \& Mueller, P. (2007). The persistence of regional new business formation-activity over time - assessing the potential of policy promotion programs. Journal of Evolutionary Economics, 17(3), 299-315.

Gould, D., \& Amaro-Reyes, J. (1983). The effects of corruption on administrative performance: illustrations from developing countries. In Gupta (Ed.), Governance, corruption \& economic performance (pp. 489-537). Washington, D.C: International Monetary Fund Publication Services.

Guest, D. (2004). Flexible employment contracts, the psychological contract and employee outcomes: an analysis and review of the evidence. International Journal of Management Reviews, 5-6(1), 1-19.

Islam, N. (1995). Growth empirics: a panel data approach. The Quarterly Journal of Economics, 110(4), 1127-1170.

Jahn, E., Riphahn, R. T., \& Schnabel, C. (2012). Flexible forms of employment: boon and bane. Laser Discussion Papers, 62, $18-19$.

Karmann, T., Mauer, R., Flatten, T. C., \& Brettel, M. (2016). Entrepreneurial orientation and corruption. Journal of Business Ethics, 133(2), 223-234.

Kher, R., Streeter, D., \& Just, D. R. (2012). The "good job" trap: opportunity cost as a deterrent to immediate venture creation. International Review of Entrepreneurship, 10(4), 127-152.

Kitching, J. (2015). Tracking UK freelance workforce trends 1992-2015. In A. Burke (Ed.), The handbook of research on freelancing and self-employment (pp. 15-28). Senate Hall: Dublin.

Leff, N. H. (1964). Economic development through bureaucratic corruption. The American Behavior Scientist, 8(2), 8-14. 
Leighton, P. \& Brown, D. (2013). Future working: The rise of Europe's independent professionals (iPros). London: PCG.

Liang, J., \& Goetz, S. J. (2016). Self-employment and trade shock mitigation. Small Business Economics, 46(1), 45-56.

Lucas, R. E. J. (1978). On the size distribution of business firms. Bell Journal of Economics, 9, 508-523.

Mankiw, N. G., Romer, D., \& Weil, D. N. (1992). A contribution to the empirics of economic growth. Quarterly Journal of Economics, 107(2), 407-437.

Marvel, M. R., Davis, J. L., \& Sproul, C. R. (2016). Human capital and entrepreneurship research: a critical review and future directions. Entrepreneurship: Theory and Practice, 40(3), 599-626.

Mauro, P. (1995). Corruption and growth. Quarterly Journal of Economics, 110, 681-712.

Murphy, K. M., Shleifer, A., \& Vishny, R. W. (1993). Why is rentseeking so costly to growth? American Economic Review, 84, 409-414.

Porter, M., Sachs, J., \& McArthur, J. (2002). Executive summary: competitiveness and stages of economic development. In M. Porter et al. (Eds.), The global competitiveness report 2001-2002 (pp. 16-25). New York: Oxford University Press.

Psacharopoulos, \& Patrinos, H. A. (2004). Return to investment in education: a further update. Education Economics, 12(2), $111-134$

Reynolds, P. D., Hay, M., \& Camp, S. M. (1999). GEM global 1999 executive report. Kansas City: Kaufman Center.

Reynolds, P. D., Bygrave, W. D., Autio, E., Cox, L. W., \& Hay, M. (2002). Global entrepreneurship monitor 2002 executive report. https://doi.org/10.13140/RG.2.1.1977.0409.

Ries, E. (2011). The lean startup. New York: Crown Business.
Storey, D. J. (1991). The birth of new firms - does unemployment matter? A review of the evidence. Small Business Economics, 3(3), 167-178.

Thurik, A. R., Carree, M. A., Van Stel, A., \& Audretsch, D. B. (2008). Does self-employment reduce unemployment? Journal of Business Venturing, 23(6), 673-686.

Unger, J. M., Rauch, A., Frese, M., \& Rosenbusch, N. (2011). Human capital and entrepreneurial success: a meta-analytical review. Journal of Business Venturing, 26(3), 341-358.

Verheul, I., Wennekers, S., Audretsch, D., \& Thurik, A. R. (2002). An eclectic theory of entrepreneurship: policies, institutions and culture. In D. B. Audretsch, A. R. Thurik, I. Verheul, \& S. Wennekers (Eds.), Entrepreneurship: determinants and policy in a European-US comparison (pp. 11-81). Boston: Kluwer Academic Publishers.

Wennekers, S., van Stel, A., Thurik, R., \& Reynolds, P. (2005). Nascent entrepreneurship and the level of economic development. Small Business Economics, 24(3), 293-309.

Wennekers, S., van Stel, A., Carree, M., \& Thurik, R. (2010). The relationship between entrepreneurship and economic development: is it U-shaped? Foundations and Trends in Entrepreneurship, 6(3), 167-237.

Wong, P. K., Ho, Y. P., \& Autio, E. (2005). Entrepreneurship, innovation and economic growth: evidence from GEM data. Small Business Economics, 24(3), 335-350.

Wooldridge, J. M. (2002). Introductory econometrics: a modern approach (2nd ed.). Ohio: South Western College Publishing.

Publisher's note Springer Nature remains neutral with regard to jurisdictional claims in published maps and institutional affiliations. 